УДК 544.6.018.

doi 10.33609/0041-6045.85.12.2019.117-127

\title{
Ю.Г.Шермолович, Т.А.Васільсва
}

\section{ІНСТИТУТУ ОРГАНІЧНОЇ ХІМIÏ НАН УКРАЇНИ - 80 РОКІВ}

${ }^{1}$ Інститут загальної та неорганічноїхімї̈ ім. В.І. Вернадського НАН Украӥни, просп. Академіка Палладіна, 32/34, Київ,03142, Украӥна

*e-mail:pogor@gmail.com

За визначенням Бориса Євгеновича Патона, Інститут органічної хімії відноситься до меморіальних установ Національної академії наук України. 23 травня 1939 року Президія АН УРСР, керуючись постановою Ради Народних комісарів УРСР від 8 травня 1939 року, прийняла рішення про створення Інституту органічної хімії і технологї АН УРСР на базі Інституту хімічної технології АН УРСР та Сектора органічної хімії Інституту хімії АН УРСР.

На момент заснування в Інституті було чотири наукові відділи, якими керували академіки АН УРСР : загального органічного синтезу - В.П. Яворський,

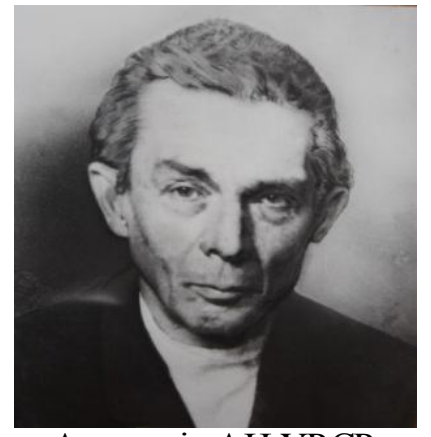

Академік АН УРСР

В.П.Яворський

(1876-1942)

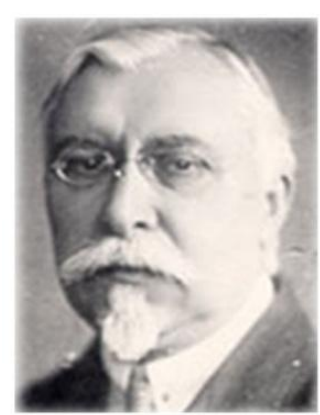

Академік АН УРСР М.І.КУзнєцов

$(1879-1959)$

палива - М.I. Кузнє цов, високомолекулярних сполук - I.К. Мацуревич, волокнистих речовин і барвників - В.Г. Шапошников. Директором Інституту було призначено академіка АН УРСР В.П. Яворського.

У передвоєнні роки Інститут працював за оборонною тематикою, зокрема займався розробкою вибухових речовин на основі органічних азидів. Коли почалася війна, Інститут було евакуйовано до Уфи, де на базі Інституту органічної хімії та Інституту хімії був створений Об'єднаний інститут хімії АН УРСР. Під час евакуації помер академік АН УРСР В.П. Яворський, директором

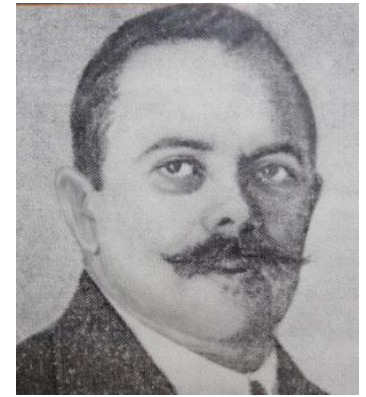

Академік АН УРСР В.Г.Ш апошников

$(1870-1952)$

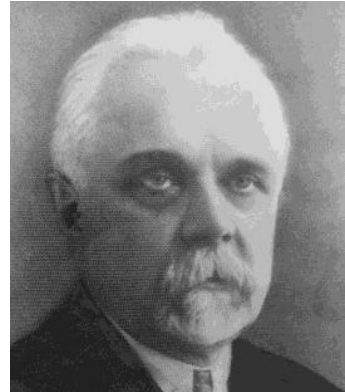

Академік АН УРСР М.I.Кузнєцов

$(1879-1959)$ 
об’єднаного інституту було призначено академіка АН УРСР Андрія Івановича

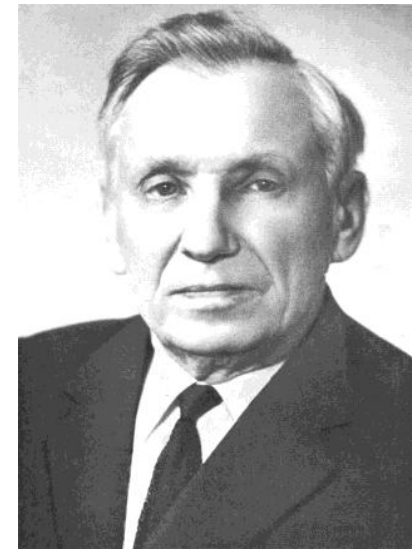

Академік АН УРСР

A.I. Кіпріанов

(1896-1972)

Директор Інституту 1942-1960 pp.

Кіпріанова. В тяжких умовах евакуації Інститут виконував оборонні замовлення, зокрема розробляв

сенс ибілізатори для високочутливих кіноплівок. За цю роботу академіка АН УРСР A.I. Кіпріанова в 1942 р. було нагороджено Державною премією СРCP. У 1944 p. Об'єднаний інститут хімії було повернуто до Києва. 28 вересня 1945 року Президія АН УРСР, керуючись постановою Ради Народних комісарів УРСР від 12 червня 1945 року, прийняла рішення про розділення Об'єднаного інституту хімії АН УРСР на Інститут загальної та неорганічної хімії АН УРСР та Інститут органічної хімії АН УРСР. Директором Інституту органічної хімії призначено академіка АН УРСР А.І. Кіпріанова.

A.I. Кіпріанов - випускник Харківського університету, учень відомого хіміка професора К.А. Красуського. До війни працював в університетах та наукових інститутах Харкова. В 1939 p. обраний членом-кореспондентом АН УРСР і його подальша діяльність була пов'язана 3 Академією наук України та Інститутом органічної хімії. В 1945-1957 pp. A.I. Кіпріанов був членом Президії АН УРСР і головою Відділення фізико- хімічних і математичних наук, потім головою Відділення хімічних і геологічних наук, був відповідальним редактором журналу "Доповіді АН України", членом редколегії "Українського хімічного журналу" та членом ВАК СРСР.

У 1944 p. А.I. Кіпріанова було запрошено завідувати кафедрою органічної хіміі Київського університету ім. Т.Г. Шевченка, яку він очолював іiі до 1960 року. Працюючи в Інституті органічної хімії АН УРСР та університеті ім. Т.Г. Шевченка, Андрій Іванович створив потужну наукову школу, яка розробила теорію кольору органічних барвників. Було відкрито явище взаємодії хромофорів, воно отримало назву «Феномен А.І. Кіпріанова». Свої наукові дослідження вчений узагальнив у монографія "Электронная теория в органической химии" та «Цвет и строение цианиновых крас ителей».

Для пояснення кольоровості органічних сполук А.I. Кіпріанов використовував теорію електронного резонансу. В сумнозвісні часи, коли було гоніння на генетику та кібернетику, під ідеологічну інквізицію потрапив і академік АН УРСР А.І. Кіпріанов. У 1951 р. в Москві на Всесоюзній нараді Відділення хімічних наук Академії наук СРСР його за сповідування теорії резонансу звинуватили у відході від матеріалістичних маркс истсько-ленінських позицій на ідеалістичні буржуазні. На той час це було дуже серйозне звинувачення. Ситуація ускладнювалась тим, що Андрій Іванович був із сім'ї священика. Він закінчив духовне училище та чотири курси духовної семінарії в Харкові, потім - природниче 
відділення Харківського університету. Завдяки отриманій освіті він мав настільки глибокі знання і був настільки блискучим полемістом, що йому вдалося відвести ідеологічні звинувачення і перевести дискусію в площину термінології. В питаннях термінології він пішов на компроміс, і таким чином врятував свій науковий напрям i відділ в Інституті органічної хімії від розгрому і закриття.

A.I. Кіпріанов та його учні B.M. Зубаровський, О.I. Толмачов, Ю.Л. Сломінський, О.О. Іщенко, К.Д. Сич, І.К. Ушенко, Ф.А. Михайленко багато зусиль приділяли впровадженню наукових розробок в практику, істотно розвинули препаративну хімію тіазолу, бензотіазолу, бензімідазолу й ряду гетероциклів. Перш за все це були фотосенсибілізатори для виробництва кінофотоплівок. Варто згадати, що перший радянський кольоровий кінофільм «Війна і мир» Сергія Бондарчука був знятий на плівці, сенсибілізованій барвником Андрія Івановича

У повоєнні роки, за час керівництва Інститутом A.I. Кіпріановим, дослідження $з$ органічної хімії значно розширились, суттєві зміни відбулись у структурі Інституту. 1947 року A.I. Кіпріанов запросив до роботи в Інституті Євгена Олексійовича Шилова, який на той час завідував кафедрою органічної Після переїзду до . Києва, Є.О. Шилов організував в Інституті органічної хімії АН УРСР відділ механізмів органічних реакцій, яким завідував до 1970 року. Є.О. Шиловим було створено наукову школу в галузі механізмів органічних реакцій. Він обгрунтував принцип донор-

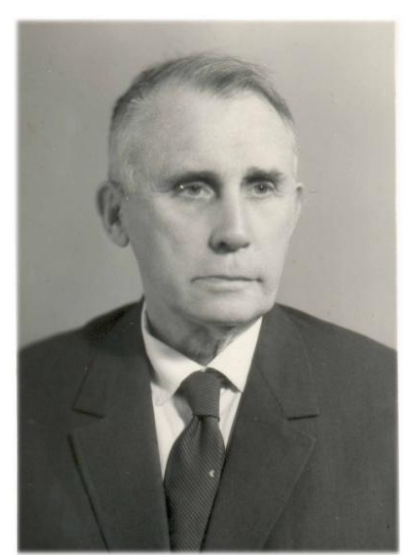

но - акцепторної взаємодії, який $\epsilon$ одним 3 основних постулатів вчення про механізми органічних реакцій. Одночас но 3 Дьюаром та незалежно від нього Свгеном Олексійовичем було обгрунтовано

Академік АН УРСР $\quad$ утворення $\pi$-комЄ.О. Шилов (1893-1970) плексів молекул ненас ичених сполук 3 електрофільними реагентами. В 1993 р. учнів Є.О. Шилова - B.I. Станінця та Ю.О. Сергучова за роботу "Проміжні часчастинки та комплекси в органічних реакціях у складі авторського колективу було відзначено Державною премією України у галузі науки і техніки.

У 1950 році Є.О. Шилов розпочав дослідження механізмів біохімічних процесів. Дослідження Свгеном Олексійовичем механізмів темнових стадій фотосинтезу у рослинах привело до заснування в Інституті 1963 року лабораторії, а потім і відділу фотосинтезу, яку очолив талановитий учень Є.О. Шилова - член-кореспондент АН УРСР Олександр Олексійович Ясніков. Під керівництвом О.О. Яснікова було розроблено теорію радикальних перетворень у реакціях, що моделюють нікотинамідні коферменти, відкрито каталітичні властивості цитохрому C у фосфорилюванні АДФ. Це були суто фундаментальні дослідження. На основі теоретичних біоміметичних підходів О.О. Ясніковим було розроблено і впровадже 
но промислову технологію одержання фосфорильованих крохмалів. Основні результати фундаментальних досліджень

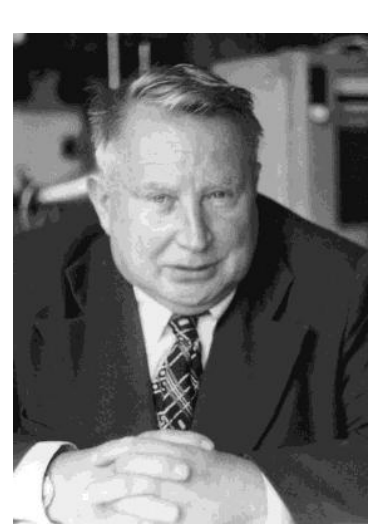

O.О. Яснікова викладені в монографіях „Органические катализаторы, коферменты и ферменты” та „Фотосинтез: химические модели и механизмы" у 1960-1983 pp. Інститут очолю- член-

кореспондент АН УРСР

О.О. Ясніков $(1923$ - 1999) вав академік АН УРСР Олександр Васильович Кірсанов. Це був найбільш стабіль ний та плідний період в історії Інституту. Держава започаткувала курс на хімізацію народного господарства. В 1970 р. Інститут переїхав 3 тісних лабораторій на вулиці Володимирській у новий корпус, що знаходиться на вулиці Мурманській (Київ). Інститут поповнився новим обладнанням, приладами, кадрами. На той час в Інституті працювало 600 співробітників, ще 350 - на Дослідному виробництві Інституту. Це був великий науково-промисловий комплекс, який доводив свої фундаментальні розробки до випуску потрібної країні хімічної продукції.

Академік АН України О.В. Кірсанов народився 1901 року в Москві у сімі інженера-транспортника. В 1912 р. він вступив до Московського кадетського корпусу, потім до Московського вищого технічного училища. В 1924 p. O.В. Кірсанов успішно завершив навчання, i його залишили аспірантом при кафедрі, яку очолював академік О. Є. Чичибабін. На кафедрі О.В. Кірсанов займався науковою та викладацькою роботою. Серед його студентів були майбутні академіки А.Ф. Плате, І.Л. Кнунянц, М.І. Кабачник.

У тридцяті роки на базі хімічного факультету МВТУ, де працював О.В. Кірсанов, було створено Військово-хімічну академію. Через непролетарське походження місця в академії вченому не знайшлося, і у 1932-1944 рр. він працює в Свердловському медичному інституті, де в 1940 р. його обрали завідувачем кафедри органічної хімії. Під час війни О.В. Кipcaнов створюе i впроваджує ефективні лікарські засоби - карбосу-

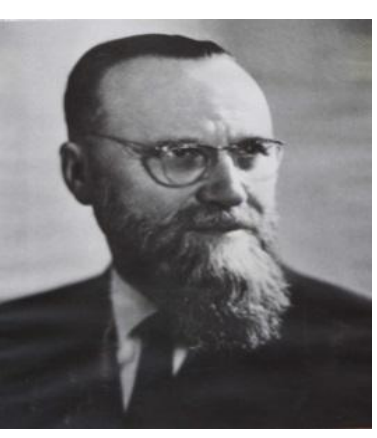

Академік АН України O.B.

Кірсанов (1901-1992) льфаміди. У 1944

p. О.В. Кірсанов

переїжджає до України і стає завідувачем кафедрою органічної хімії Дніпропетровського металургійного інституту. В 1945 p. йому присвоюють військове звання i відряджають до Німеччини за спеціальним завданням наркома чорної металургії. В Дніпропетровську О.В. Кірсанов розпочав роботи 3 хімії фосфороорганічних сполук. У 1956 р. він, на запрошення академіка АН УРСР А.І. Кіпріанова, переїздить до Києва, очолює лабораторію, потім відділ. У 1960 р. стає директором Інституту, розгортає повномасштабні дос- 
лідження в хімії фосфорорганічних сполук, створює свою наукову школу.

Олександр Васильович вивчав історію науки і встановив, що його наукова школа походить від Лібіха по такому ланцюжку: Лібіх - Зінін - Бутлеров Марковников - Чичибабін - Кірсанов. О.В. Кірсанов писав про наукові школи так: «Перша у світі наукова школа (якщо не вважати Греції і Рима) була школа Лібіха, і вона породила багато наукових шкіл Європи. У цих школах їх очільники прагнули до того, щоб не тільки вони, але і їхні учні були генераторами ідей, щоб вони виявляли максимум ініціативи i, отже, надалі могли 3 успіхом працювати самостійно, а не бути тільки вправними лаборантами при очільнику школи». Саме на таких засадах О.В. Кірсанов створив свою школу, яка продовжується і розвивається. Його учні - академіки Л.М. Марковський і В.П.Кухар заснували свої наукові школи, очолювали великі наукові колективи.

Талановитим учнем О.В. Кірсанова був його заступник 3 наукової роботи член-кореспондент Г.I. Деркач, який створив новий напрямок у хімії фосфороорганічних сполук - хімію ізоціанатів фосфору. На жаль, він у 37 років загинув в автомобільній катастрофі.

У 1965 р. було створено відділ хімії комплексоутворюючих фосфорорганічних сполук, яким керувала доктор хімічних наук Н.Г. Фещенко. У відділі успішно розвивалась хімія йодидів фосфору. На цьому напрямі було отримано науковопрактичні результати 3 розробки та промислового впровадження передової технології одержання фосфіноксидів, що за- стосовуються для вилучення урану i трансуранових елементів 3 руд, а також для переробки відходів атомних електростанцій. Ці фундаментальні дослідження привели до розробки технологічного методу отримання триалкілфосфіноксидів, який був впроваджений спочатку на Дослідному виробництві Інституту, а потім на гірничо-збагачувальному комбінаті в Мангишлаку. Триалкілфосфі нокс иди знайшли широке викорис тання як екстрагенти рідкоземельних металів та актинідів в гідрометалургії і радіохімічній промисловості. Ця розробка була відзначена премією Кабінету Міністрів СРСР (1987р.).

O.В. Кірсанов запросив на роботу в Інститут молодого талановитого хіміка Ю.Г. Гололобова з Москви. Юрій Григорович був заступником директора 3 наукової роботи, довгий час очолював відділ хімії елементоорганічних сполук, зробив значний внесок в цю галузь науки, був обраний членом-кореспондентом АН України. У відділі вивчались геретозаміщені іліди фосфору, галогенотропні міграції, прототропія у фосфор-вуглецевій системі, фосфазоілідна таутомерія, циклізації та перегрупування ілідних с истем.

Заступником директора $з$ наукової роботи Інституту О.В. Кірсанова був А.Д.Синиця. До його чисельних наукових здобутків відноситься розробка методів синтезу і дослідження властивостей імінофосфонатів. Займався також прикладними розробками для народного і сільського господарства, оборонної промисловості. Під керівництвом А.Д. Синиці розроблений і впроваджений на КБ Південне стабілізатор епоксидних смол, завдяки якому був створений найкращий у світі 
за ваговими параметрами корпус твердопаливного ракетного двигуна.

До плеяди наукової школи О.В. Кірсанова входить знаний хімік, членкореспондент НАН України O.I.Колодяжний. Його дослідження в галузі фосфорорганічних сполук, зокрема в хімії ілідів фосфору, добре відомі світовій науковій спільноті.

O.В. Кірсанова пов'язували плідні професійні стосунки і людська дружба 3 відомими вітчизняними та зарубіжними хіміками. Він мав дружні стосунки 3 двічі нобелевським лауреатом Лайнусом Полінгом.

О.В. Кірсанов увіковічив себе в науці двома іменними реакціями - реакція аміносполук 3 пентахлоридом фосфору та реакція окиснювального імінування сполук тривалентного фосфору дихлорамінами. Ці дві реакції є основними методами отримання фосфазосполук.

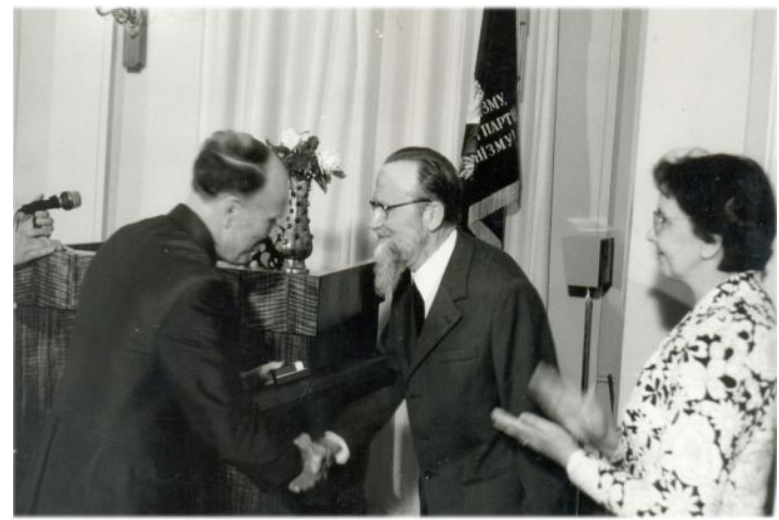

Б.С.Патон вручає О.В. Кірсанову диплом лауреата Ленінської премії 1974 р.

Держава гідно оцінила наукову діяльність О.В. Кірсанова: за дослідження в галузі фосфорорганічних сполук йому в 1974 р. була присуджена Ленінська премія.
У 1983 р. директором Інституту було призначено Л.М. Марковського, учня О.В. Кірсанова. На той час йому виповнилось всього 44 роки.

Л.М.Марковський закінчив «Львівську політехніку» і вступив до аспірантури Інституту органічної хімії АН УРСР.

Науковим керівником Л.М. Марковського була професор К.С.Левченко - відомий вчений в області сіркоорганічних наук. Вона займалась дослідженням реакцій окислювального імінування сірки, селену та їх неорганічних сполук. Результати цих досліджень знайшли широке в изнання і успішно використовуються в науковій практиці.

Л.М. Марковський був блискучим експериментатором. Його кандидатська, а потім і докторська дисертація були присвячені хімії сіркоорганічних сполук. Він виконав прекрасні роботи, які вимагали надзвичайної майстерності. Л.М. Марковським разом 3 аспірантом, В.Ю. Пашинником, майбутнім професором, було винайдено діалкіламіно трифторсульфурани. Діалкіламінотрифторсульфурани є м'якими і селективними фторуючими реагентами, які знайшли широке застосування в синтезі біологічно активних фторовмісних сполук.

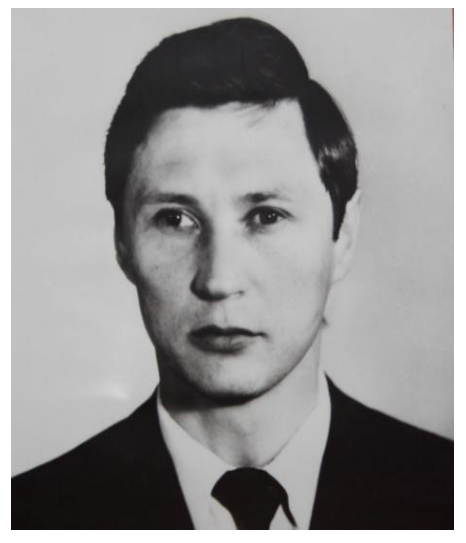

Академік НАН України Л.М. Марковський (1939-1998) директор Інституту (1983-1998pp.) 
Інституту органічної хімії НАН украӥни - 80 років

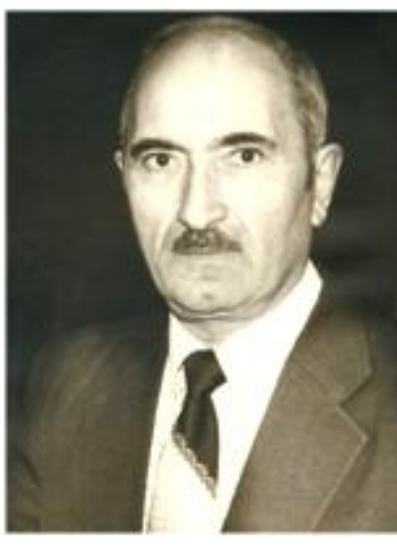

Професор

Л.М. Ягупольський

(1922-2009)
Коло наукових інтересів Л.М. Марковського було надвичайно широке. Окрім сірко- та фтороорганічної хімії, він займався сполуками 3 некласичною координацією атома фосфору похідними гіпота гіперкоординованого фосфору, а також зовсім новою на той час хімією фосфоровмісних краун-етерів. У 1991p. за дослідження в галузі краунетерів Л.М.Марковський одержав Державну премію України в галузі науки і техніки. Окрім фундаментальних досліджень, багато часу і енергії Леонід Миколайович присвячував прикладним розробкам. На Дослідному виробництві Інституту ним було налагоджено випуск інгібіторів горіння полімерних матеріалів та субстанцій лікарських препаратів i пестицидів.

Всесвітньо відома наукова школа 3 хімії фтору була створена в Інституті професором Л.М. Ягупольським. Лев Мойсеєвич пройшов славетний життєвий шлях. У 1939 р. він вступив на хімічний факультет Київського університету ім. Т.Г. Шевченка, але почалася війна, як хіміка його було направлено на навчання до Військово-хімічної академії в Самарканді. Війну Л.М. Ягупольський закінчив начхімом дивізії у званні капітана і повернувся до навчання в рідний уні- верс итет.

Після закінчення універс итету він вступив до аспірантури під науковим керівництвом

A.I. Кіпріанова. Пропонуючи своєму аспіранту тему кандидат-

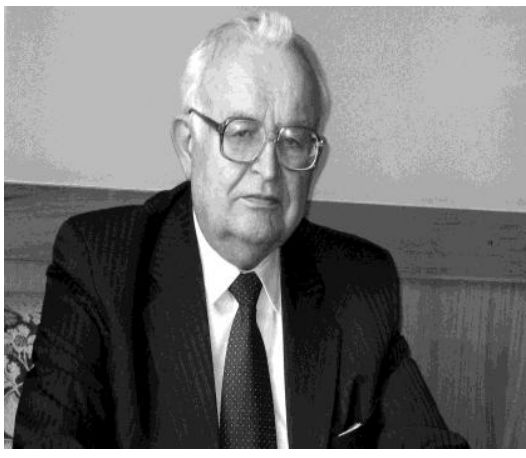

Академік НАН України М.О. Лозинський (1933-2011) Директор Інституту (1998-2011) ської дисертації з синтезу ціанінових барвників, які містять фтор, А.I. Кіпріанов зауважив: "Хімія фтороорганічних сполук, особливо гетероциклічних, дуже мало вивчена, в нашій країні опублікованих праць у цій області немає. Я сам зі сполуками фтору ніколи не працював. Спробуйте. Якщо у Вас нічого не вийде, тему змінимо”. У Л.М. Ягупольського все вийшло і його роботи започаткували хімію фтороорганічних сполук в Україні. Після захисту кандидатської дисертації в 1951 p. Л.М. Ягупольського було направлено на роботу в Інститут органічної хімії $\mathrm{AH}$ УРСР у відділ кольору та будови органічних сполук, який очолював академік А.I. Кіпріанов. Завдяки зусиллям Л.М. Ягупольського і співробітників відділу, розпочався стрімкий розвиток нового наукового напрямку в галузі хімії елементоорганічних сполук - хімія ароматичних та гетероциклічних сполук $з$ фторовмісними замісниками. Інтенс ивно проводились дослідження з синтезу ціанінових барвників 3 фторовмісними замісниками в гетероциклічних ядрах i 3 атома 
ми фтору та перфтороалкільними групами у поліметиновому ланцюзі.

На початку 90-х років Л.М. Ягупольським сформульовано принцип конструювання надсильних $\mathrm{CH}, \mathrm{NH}$ та $\mathrm{OH}$ кислот шляхом введення в молекулу електроноакцепторних фторовмісних сульфогруп. Він відомий у світовій літературі як принцип Ягупольського. Відкрив також реакцію прямого каталічного амінування галоїдаренів, яка зараз відома як реакція Бухвальда-Хартвіга-Ягупо льського. Л.М. Ягупольським розроблено і впроваджено у медичну практику низку лікарських препаратів. Заслуги Льва Мойсейовича були відзначені державною премією УРСР, премією Ради міністрів Латвійської РСР, державною премією України. Він створив потужну наукову школу 3 хімії фтору. Під його керівництвом захистилось 90 кандидатів та 11 докторів наук.

Достойним послідовником справи Льва Мойсейоича $є$ його син, профессор Ю.Л. Ягупольський. Він успішно керує відділом хімії фтороорганічних сполук 3 1988 року.

У 1998-2011 pp. директором Інституту було призначено М.О. Лозинського. Він отримав хіміко-технологічну освіту в Львівській політехніці. Працював у Рубіжному, потім вступив до аспірантури Інституту органічної хімії АН УРСР. Захистив кандидатську дисертацію під керівництвом П.С. Пелькіса. Враховуючи технологічну освіту, організаторські здібності та енергію Мирона Онуфрійовича, О.В. Кірсанов направив його працювати на відповідальні посади щойно створеного
Дослідного виробництва Інституту. Багато зусиль М.О. Лозинський приділяв розробці субстанцій лікарських препаратів, створенню їх технологій та впровадженню в практику. Академіком С.В. Комісаре нком спільно з М.О. Лозинським було розроблено вітчизняний протипухлинний препарат МЕБІФОН. М.О. Лозинський вдало поєднував прикладні та фундаментальні дослідження. Він був відомим спеціалістом у галузі хімії фізіологічно активних гетероциклічних сполук. У 2003 р. вченими радами Інституту органічної хімії НАН України та націо нального фармацевтичного університету було започатковано випуск нового наукового видання - Журналу органічної та фармацевтичної хімії.

Наукову та винахідницьку діяльність М.О. Лозинського було гідно оцінено державою та науковою спільнотою. Він мав численні урядові нагороди, був удостоєний звання почесного доктора своєї альма-матер Львівської політехніки.

32011 року Інститут очолює акаде-

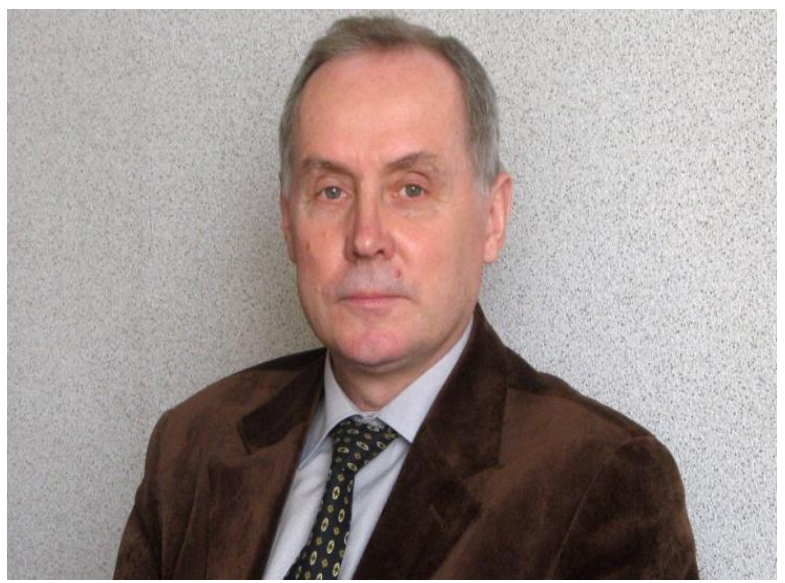

Академік НАН України B.I. Кальчен ко Директор Інституту (з 2011 р.) 
мік НАН України В.І. Кальченко. Народився у м. Ворожба на Сумщині. У 1972 p. закінчив із відзнакою Київський політехнічний інститут. Понад 45 років працює в Інституті органічної хімії НАН України, де з 1998 року очолює відділ хімії фосфоранів. В.І. Кальченко - лауреат Державної премії України в галузі науки і техніки, нагороджений грамотами Кабінету міністрів України та Верховної Ради України, відзнаками НАН України. В.I. Кальченко - почесний доктор НТК «Інститут монокристалів» НАН України та Інституту неорганічної хімії ім. А.В. Ніколаєва СВ РАН.

Віталій Іванович - фахівець у галузі органічної, біоорганічної, фосфороорганічної та супрамолекулярної хімії. Він учень академіків О.В. Кірсанова та Л.М. Марковського. В.І. Кальченко зробив вагомий внесок у хімію фосфороорганічних сполук 3 нетрадиційною координацією атома фосфору. Він запропонував перспективний підхід до синтезу циклічних (макроциклічних) похідних гексакоорд инованого фосфору, систематично дослідив фосфоротропні таутомерні міграції, які моделюють елементарні стадії реакцій фосфору, в тому числі процеси біофосфорилювання. На даний час дослідження B.I. Кальченка спрямовані на молекуля рний дизайн, синтез та вивчення супрамолекулярних взаємодій макроциклічних сполук - краунетерів, каліксаренів, тіакаліксаренів та каліксрезорцинаренів. Він синтезував оригінальні фосфоровмісні каліксарени, які за ефективністю та селективністю екстракції актинідів, лантанідів, металів платинової групи, технецію (основних компонентів відпрацьованого ядерного палива) перевищують відомі на сьогодні промислові екстрагенти.

B.I. Кальченко є знаним у світі вченим. Він працював запрошеним професором у західних університетах, виступав 3 пленарними доповідями на багатьох міжнародних конференціях, входить до складу організаційних комітетів низки конференцій.

B.I. Кальченко розробив і впровадив на Дослідному виробництві Інституту органічної хімії НАН України технологію синтезу субстанції протипухлинного препарату «Мієлосан», що дало змогу повністю задовольняти потреби України в цьому лікарському засобі. Створено та впроваджено термостабілізатори полімерних матеріалів спеціального призначення для авіаційної та ракетнокосмічної техніки.

На сьогодні в Інституті на світовому рівні проводяться фундаментальні дослідження $з$ цілеспрямованого молекулярного дизайну та синтезу нових типів фізіологічно активних гетероциклічних та макроциклічних сполук. Розробляються стереоселективні методи синтезу енантіомерно чистих органічних сполук різноманітних класів. Створюються нові методи фторування.

Інноваційні розробки Інституту спрямовані на створення лікарських препаратів, фізіологічно активних речовин для медицини та ветеринарії; ціанінових барвників для фотовольтаїки, голографії, лазерної техніки; каталізаторів органічних реакцій для хімічної промисловості; в исокоселективних комплексоутворювачів молекул 
іонів для сенсорних пристроїв, екстрагентів та сорбентів радіонуклідів. Пріорітетними для Інституту є міждисциплінарні інноваційні наукові розробки, які виконуються у співпраці 3 вітчизняними та іноземними науковцями 3 використанням синтезованих в Інституті сполук. В Інституті мікробіології та вірусології ім. Д.К. Заболотного НАН України встановлено, що синтезовані в Інституті органічної хімії оригінальні фторовмісні нуклеозиди за своєю ак-тивністю перевищують відомий анти-вірус ний препарат Ацикловір. У спів-праці з науковцями Інституту фізіології ім. О.О. Богомольця НАН України показано, що похідні амідинокумарину з рекордною ефективністю пригнічують $\mathrm{pH}$-чутливі йонні канали і $\epsilon$ потенційними антиішемічними препаратами. У спіль-ному проекті Інституту органічної хімії, Інституту загальної та неорганічної хімії ім. В.І. Вернадського НАН України та Київського національного університету імені Шевченка показано, що комплексні сполуки похідних 2амінотіазолу 3 міддю та паладієм мають виражену анти-проліферативну дію i $\mathrm{\epsilon}$ перс пективними для створення протипухлинних препа-ратів. У спільному проекті 3 Інститутом харчової біотехнології і геноміки НАН України проведено дизайн інгібіторів синтезу білка в клітинах мікроорганізмів. У результаті знайдено хітсполуки, перспективні для створення нових протитуберкульозних препаратів. На замовлення МВС України Інститутом було виконано науково-дослідну роботу по створенню запахових реквізитів наркотичних речовин для тренування службових собак кінологічних підрозділів. За ре- зультатами цього проекту розроблено імітатори запаху наркотичних речовин, які захищені патентами України і знаходяться на стадії впровадження.

Великий інноваційний потенціал мають синтезовані в Інституті органічні барвники. Спільно з Інститутом високих технологій універс итету ім. Тараса Шевченка на основі барвників були створені люмінесцентні сонячні конвертори для підвищення ефективності кремнієвих фотоелектричних перетворювачів.

Затребуваними об'єктами міждисциплінарних інноваційних розробок $\epsilon$ каліксарени - чашоподібні макроциклічні сполуки, які здатні утворювати супрамолекулярні комплекси 3 біологічно значими молекулами та йонами. Спільно 3 академіком НАН України С.В. Комісаренком показано, що каліксаренметиленбісфосфонові кислоти утворюють супрамолекулярні комплекси 3 фібрином і гальмують його полімеризацію. На даний час такі кислоти проходять доклінічні дослідження, метою яких є створення антитромботиків. Спільно 3 академіком НАН України С.О. Костеріним було знайдено ефективні і селективні каліксаренові інгібітори АТФ залежних іонних насосів у клітинах гладеньких м'язів. Такі сполуки є потенційними препаратами для лікування патологій, викликаних порушеннями іонного обміну. Низка синтезованих каліксаренів вивчалась в Інституті біоорганічної хімії та нафтохімії ім. В.П.Кухаря НАН України членом-кореспондентом НАН України A.I. Вовком. Встановлено, що каліксаренфосфонові кислоти $є$ ефективними та селективними інгібіторами терапевтично 
важливих фосфатаз різноманітного походження. Вони мають перспективу застосування при лікуванні діабету та як протипухлинні препарати. Актуальною медичною проблемою $є$ розробка препаратів для подолання лікарської резистентності. В Інституті експериментальної патології, онкології та радіобіології ім. Р.В. Кавецького НАН України академіком В.Ф. Чехуном показано, що каліксаре нметиленбісфосфонова кислота інгібує дію Р-глікопротеїнів, які видаляють ксенобіотики з клітин, і таким чином знижує їх резистентність до протипухлинного препарату “Доксорубіцин”.

Традиційною тематикою Інституту, яка активно розвивається, є розробка комплексоутворювачів радіонуклідів. На основі синтезованих каліксаренових комплексоутворювачів колегами 3 НТК «Ннтитут монокристалів» НАН України створено сорбенти, що ефективно і селективно видаляють радіонукліди із забруднених природних чорноб ильської електростанцій.
В Інституті фізики напівпровідників iм. В.С. Лашкарьова НАН України на основі каліксаренів було сконструйовано хемосенсор «Електронний ніс». Створений сенсор - це інтелектуальна система, яка здатна розпізнавати пари органічних сполук у повітрі, формувати їх цифровий образ, зберігати його в електронній пам'яті i використовувати при аналізі токсичних речовин та для контролю якості харчових продуктів, напоїв, парфумів тощо.

За багаторічну історію співробітниками Інституту опубліковано 8000 наукових статей i видано 90 монографій, одержано 1550 авторських свідоцтв та патентів. Інститутом підготовлено 350 кандидатів та 65 докторів наук. Розробки Інституту було широко впроваджено в медицину, народне господарство, оборонну промисловість. За свої наукові досягнення, впровадження результатів досліджень, підготовку наукових кадрів Інститут удостоєний високих державних нагород і премій. 